\title{
Anti-Lu14: A Lutheran Antibody Defining the Product of an Allele at the Lu8 Blood Group Locus ${ }^{1}$
}

\author{
W. J. Judd, W. L. Marsh, R. Oyen, M. E. Nichols, F. H. Allen, jr., M. Contreras \\ and M. Stroup
}

Department of Pathology, University of Michigan, Ann Arbor, Mich.: Lindsley F. Kimball Research Institute of the New York Blood Center, New York, N.Y.; North London Blood Transfusion Centre and the MRC Blood Group Unit, London; and the Philip Levine Laboratories, Ortho Research Foundation, Raritan, N. Y.

\begin{abstract}
A 'new' Lutheran-related antibody, named anti-Lu14, reacts with approximately $2.4 \%$ of random bloods. Red cells of the rare $\mathrm{Lu}:-8$ phenotype are Lu: 14 . The data indicate, with a high probability, that the $L u 14$ antigen is a product of an allele of $L u^{8}$ and that $L u^{14}$ and $L u^{8}$ comprise a third pair of alleles at the Lutheran locus. Red cells of the original Sw (a+) propositus are Lu:14. By coincidence, he has inherited two low-incidence genes. This observation may explain the discrepancy in different families concerning a possible relationship between $S w^{a}$ and Lutheran. Pedigree information now suggests that $S w^{\mathrm{a}}$ is not a Lutheran gene.
\end{abstract}

A number of antibodies have been found that identify high-incidence red-cell antigens related to the Lutheran blood group system. The relationship is shown by their failure to agglutinate $\mathrm{Lu}(\mathrm{a}-\mathrm{b}-)$ red cells of either dominant or recessive types of inheritance. Thus, anti-Lu4 [1], anti-Lu5, anti-Lu6, anti-Lu7 [5], anti-Lu8 [7], anti-Lu11 [4], and anti-Lu12 [11] define common red cell antigens, but incompatibility between these blood samples establishes that different specificities must be involved.

Anti-Lu9 defines an uncommon Lutheran antigen that has a phenotype frequency of about $2 \%$ [10]. Lu9 and Lu6 have an

1 Supported in part by grant HL-09011 from the National Heart and Lung Institute, NIH. antithetical relationship: except for $\mathrm{Lu}$ (a-b-) samples, all Lu:-6 bloods have been Lu:9. Family studies have established these to be products of a second pair of allelic genes at the Lutheran locus.

We have studied the serum of a Caucasian patient, Mrs. Hof, which contains another antibody defining a low-frequency red-cell antigen related to the Lutheran blood group. The patient had chronic renal failure and underwent hemodialysis at twice-weekly intervals until her death in early 1975 . She was given many blood transfusions. The antibody, which has been named anti-Lu14, reacts with about $2.4 \%$ of random Caucasian blood samples and appears to recognize an antigen that is antithetically related to Lu8.

During the investigation, we have found that the propositus of the Swann (Swi) family reported by Cleghorn [3] is Lu:14. 
In view of the evidence associating $\mathrm{Sw}^{\text {at }}$ with the Lutheran blood group, data on the Lul4 status of the Swann family is included in this report.

\section{Serological Results}

\section{Red Cells}

Extensive typing of Mrs. Hof's red cells revealed nothing unusual in her antigenic profile. The direct antiglobulin test was negative. Her Lutheran phenotype was Lu(a-b+), Lu: 3, 4, 5, 6, 7, 8, -9, 11, 12. In litration studies with anti-Lub and anti-Lu6 her red cells reacted as strongly as did homozygous positive control cells.

\section{Serum}

Anti-Lu14 reacts by indirect antiglobulin test using both broad spectrum and specific anti-IgG antiglobulin reagents. Its serological activity is not destroyed by treatment with 2-mercaptoethanol, confirming that it is an $\mathrm{IgG}$ protein. It is not inhibited by saliva from $\mathrm{ABH}$ secretors or nonsecretors, or by hydatid cyst fluid. Absorption and elution studies using different examples of reactive red cells indicate that the serum is monospecific. Reactivity of the Lul4 antigen is neither enhanced nor depressed by treatment of reactive red cells with ficin or papain.

During the initial study, the serum was tested against an extensive range of red cell samples known to possess low-incidence antigens. Cells from the original $(\mathrm{Sw}(\mathrm{a}+)$ donor were reactive, but all other samples were nonreactive. Other examples of the Sw $\left(\mathrm{a}_{+}\right)$phenotype did not react, and a random Lu:14 donor was found to be Sw(a-). Furthermore, an absorption and
Table I. Results given by anti-Lu 14 after absorption and elution using Sw(a+), Lu:14 red cells

\begin{tabular}{lll}
\hline Red cells & $\begin{array}{l}\text { Reactivity of eluted } \\
\text { antibody }\end{array}$ \\
\cline { 2 - 3 } & result & score [6] \\
\hline Sw (a $),$ Lu: 14 & positive & 8 \\
Sw (a $:)$, Lu: 14 & negative & 0 \\
Sw (a ), Lu: 14 & positive & 8 \\
Sw (a ), Lu: 14 & negative & 0 \\
\hline
\end{tabular}

Tests by antiglobulin method.

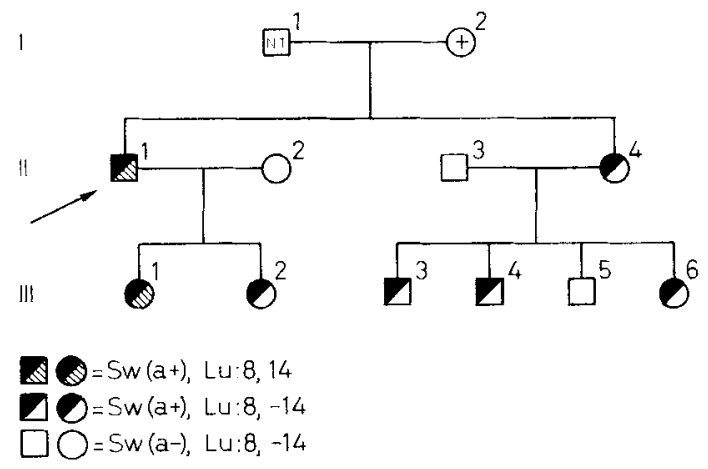

Fig. 1. Pedigree of the Swann family showing inheritance of $S w^{\text {a }}, L u^{8}$, and $L u^{14}$. I-1 is $S w(a-)$ but was not tested for Lu8 and Lul4.

elution study with the Hof serum, using red cells from the reactive $\mathrm{Sw}(\mathrm{a}+)$ donor, yielded an eluate that reacted with other Lu:14 cell samples but not with a red cell sample that was $\operatorname{Sw}\left(\mathrm{a}_{+}\right)$, Lu:-14. Serological results obtained in these antibody absorption and elution studies are summarized in table $I$. It could be concluded from these observations, and from the difference in frequency between the $\mathrm{Sw}(\mathrm{a}+)$ and $\mathrm{Lu}: 14$ phenotypes, that anti-Swa and anti-Lu14 are not the same antibody and that the simultaneous presence of Swa and Lu14 on the red cells 
Table II. The reactions given by anti-Lu 14 against selected red cell samples

\begin{tabular}{|c|c|c|c|c|c|c|c|}
\hline \multirow[t]{2}{*}{ Red cells } & \multicolumn{6}{|c|}{ Reciprocals of dilutions of anti-Lu 14} & \multirow[t]{2}{*}{ Score $[6]$} \\
\hline & 1 & 2 & 4 & 8 & 16 & 32 & \\
\hline Lu: $-8,14$ (1) & 8 & 7 & 6 & 5 & 3 & 0 & 29 \\
\hline Lu: 8,14 (2) & 9 & 8 & 6 & 5 & 2 & 0 & 30 \\
\hline Lu:8, 14 (1) & 6 & 5 & 2 & 0 & 0 & 0 & 13 \\
\hline Lu: 8,14 (2) & 6 & 5 & 2 & 0 & 0 & 0 & 13 \\
\hline Lu: $8,-14$ & 0 & 0 & 0 & 0 & 0 & 0 & 0 \\
\hline
\end{tabular}

Tests by antiglobulin technique.

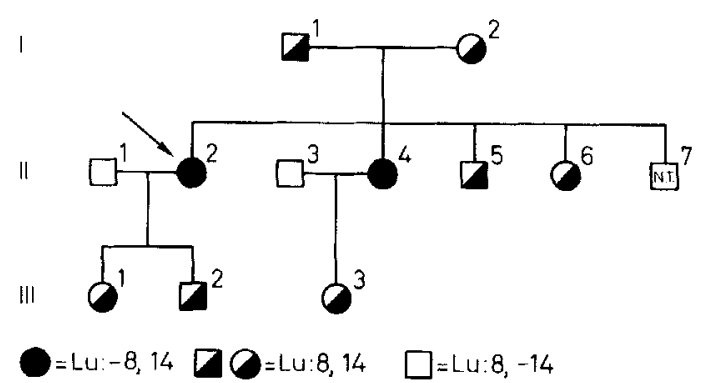

Fig. 2. Lu: 8 and Lu: 14 phenotypes of the M.T. family. All members are Lu(a-b+).

of the propositus of the original $\mathrm{Sw}^{\mathrm{a}}$ investigation is probably a coincidence. The blood groups of the Swann family provide further evidence of independence. The propositus is $\operatorname{Sw}(\mathrm{a}+), \mathrm{Lu}: 8,14$, but his sister is Sw(a+), Lu:8, -14 . Both of his children received his $S w^{\prime \prime}$ gene but only one received $L u^{14}$. The pedigree of this family, which was first published by Cleghorn [3], is shown in figure 1.

\section{Relation to Lu8}

Anti-Lu14 did not react with any red cell samples from an extensive collection selected for their lack of different highfrequency antigens in other blood group systems. Red cell samples that lacked Lu4,

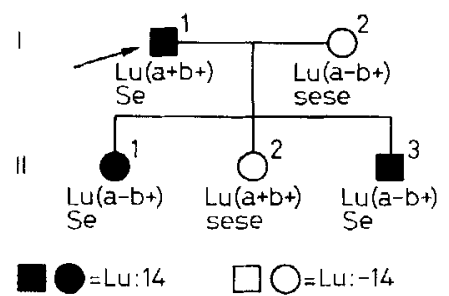

Fig. 3. Pedigree of the Ri. family. $L u^{14}$ is apparently segregating with $S e$ and $L u^{\mathrm{b}}$.

Lu5, Lu6, Lu7, Lu11, or Lu12 were nonreactive with the Hof serum, as were cells of $\mathrm{Lu}(\mathrm{a}-\mathrm{b}-)$ phenotype, but an Lu:-8 sample was strongly agglutinated (table II). Only two other unrelated Lu:-8 people are known and red cells of both are Lu:14. The results of tests with anti-Lu14 on red cells of the M. T. family of Maclloy et al. [7] in which two members are $\mathrm{Lu}:-8$, are shown in figure 2. The parents and all blood relatives have the Lu:14 phenotype. A sister of another unrelated Lu:-8 person has red cells that react weakly with anti-Lu8 and are also Lu:14. In titration studies, using anti-Lu14, red cells of Lu:-8 people react more strongly than do cells from random people of Lu:14 phenotype (table II). 
Frequency of the Lu:14 Phenotype

Of 580 random donor bloods, mostly from Caucasians, 14 were $\mathrm{Lu}: 14$, a phenotype frequency of 0.024 . All of the Lu:14 samples in this series were $\mathrm{Lu}\left(\mathrm{a}-\mathrm{b}_{+}\right)$. In further tests of 220 selected $\mathrm{Lu}(\mathrm{a}+\mathrm{b}+)$ samples, only one Lu:14 blood was encountered. This finding is suggestive of linkage disequilibrium with $\mathrm{Lu}^{\mathrm{a}}$, for about five would be expected otherwise. If it is assumed that 0.024 is the true frequency of Lu14, the probability that such apparent disequilibrium would occur by change is 0.03 .

\section{Linkage with Lutheran}

The pedigree of the $\mathrm{Lu}(\mathrm{a}+\mathrm{b}+), \mathrm{Lu}: 14$ donor (Mr. $\mathrm{Ri}$ ) is shown in figure 3 . One of his children is Lu:-14, so the father must be heterozygous for the $L u^{1 t}$ gene. Since II-2 is an ABH nonsecretor (sese), the propositus must also be heterozygous for the $S e$ gene. In this double back-cross mating the two children who inherited his $L u^{\prime \prime}$ and $S e$ genes received $L u^{t}$, while the daughter who did not inherit $L u^{14}$ received his $L u^{u}$ and se genes. $L u^{t 4}$ is apparently segregating with $L u^{b}$ and $S e$ in this family $\left(Z_{1}\right.$ score is $\left.3: 0\right)$. The probability that this segregation would occur by chance is about 0.25 . When this figure is combined with the figure for linkage disequilibrium (see above), they give a confidence level of 0.9925 that Lu14 belongs in the Lutheran system.

\section{Discussion}

The pedigrees that are presented establish that Lu14 is inherited as an autosomal dominant characteristic. The finding that the parents (I-1 and I-2) and all of the children of the M. T. family have the Lu:14 phenotype, and furthermore that the two Lu:-8 offspring have exceptionally strong Lu14 antigens, suggests that $L u^{8}$ and $L u^{14}$ have an allelic relationship. That two other unrelated Lu:-8 people are also Lu:14 is further support for such a relationship, for the probability that three unrelated Lu:-8 people would be Lu:14 by chance is 0.000021 . The exceptionally strong reaction with anti-Lu14 given by red cells that are $\mathrm{Lu}:-8$ is consistent with their assumed homozygous $L u^{14}$ status. The phenotypic relationship of Lu8 to the Lutheran system has been established by the finding that $\mathrm{Lu}(\mathrm{a}-\mathrm{b}-)$ red cells are Lu:-8. The recessive Lu(a-b-) phenotype almost certainly arises by homozygous inheritance of a silent $L u$ allele [2]. Such cells are not known to have any phenotypic aberration outside of the Lutheran blood group and the finding that they are Lu:-8 is strong evidence that $\mathrm{Lu} 8$ is a product of the Lutheran gene complex. The occurrence of apparent linkage disequilibrium with Lutheran, and the evidence in the $\mathrm{Ri}$. family of linkage between $L u^{14}$ and the secretor and Lutheran loci, all provide support for concluding that $L u^{14}$ is a Lutheran gene. It cannot be another allele at the $\mathrm{Lu}^{\mathrm{a}} \mathrm{Lu}^{\mathrm{b}}$ mutational site, however, for $\mathrm{Lu}(\mathrm{a}+\mathrm{b}+)$ red cells can be Lu:14. Another mutational site must be involved.

The combined probability that all of these associations with the Lutheran blood group are occurring by chance is $2.75 \times 10^{7}$. There is, thus, a considerable weight of evidence to show that $L u^{14}$ is a Lutheran gene and that $L u^{8}$ and $L u^{14}$ comprise a third pair of alleles at the Lutheran locus.

The Lu:14 phenotype frequency is 0.024 and if allowance is made for a silent $L u$ gene with an estimated frequency of 0.01 , 
the Lu:-8 phenotype frequency can be calculated as about 0.0005 , or 1 in every 2,000 individuals.

A little of the fog that surrounds the Swann-Lutheran relationship may be dispersed by the finding of anti-Lu14. Cleghom [3] in 1960 found a modest hint that the Swa and $\mathrm{ABH}$ secretor gene loci may be linked. In view of the known linkage between the Lutheran and secretor loci [9, 12] it appeared possible that $\mathrm{Sw}^{\mathrm{a}}$ might be part of the Lutheran complex. A family reported by Metaxas-Bühler et al. [8] provided support for this possibility, for in this family $L u^{a}$, $S e$, and $S w^{a}$ were segregating in four generations with no recombinants. But another family, found later by Metaxas [personal commun., 1973], appeared to confound this relationship, for it contained members in whom $S w^{\prime \prime}$ and $L u^{\prime \prime}$ were segregating, but either 3 or 4 of them were recombinants.

The red cells of Mr. Swann have been widely distributed and used for identification of anti-Swa. But the donor is now known to have two low-incidence antigens, $\mathrm{Sw}^{\mathrm{a}}$ and Lul4. It is possible, therefore, that some antisera designated as anti-Swa might be anti-Lu14, or a mixture of the two, thus providing an explanation of the discrepant family results.

The Swann family and their Lu14 phenotypes provide some information concerning the relationship of $\mathrm{Sw}^{\mathrm{a}}$ to Lutheran. $S w^{a}$ appears to be inherited as an autosomal dominant characteristic [3]. Mr. Swann must be heterozygous for the $S w^{a}$ gene because one of his parents is known to be Sw(a-). He has $S w^{a}$ and $L u^{t t}$, but contributed $S w^{a}$ and not $L u^{14}$ to one of his children. If $S_{w}$ a were a Lutheran gene, the two cannot be on the same chromosome as part of one Lutheran gene complex. But his second child received both $S w^{a}$ and $L u^{H}$ and this would not be possible if $S w^{a}$ were a Lutheran gene, for in this case the propositus could contribute $S w^{a}$ or $L u^{14}$, but not both. There is a substantial weight of evidence to argue that $L u^{14}$ is an allele at the Lutheran locus, and the data, therefore, suggest that $S w^{a}$ is not closely linked to the Lutheran gene complex.

\section{Acknowledgements}

We are grateful to the Swann, Taylor and Rizzo families for their generous cooperation, and to Dr. G. de Gabriele and Ms. G. Kaczmarski who sent us blood samples that proved to be Lu:-8.

\section{References}

1 Bove, J. K.; Allen, F. H., jr.; Chiewsilp, P.: Marsh, W. L., and Cleghorn, T. E.: Anti-Lu4. A new antibody related to the Lutheran blood group system. Vox Sang. 21: 302-310 (1971).

2 Brown, R.; Simpson, S.; Cornwall, S.; Moore, B. P. L.; Øyen, R., and Marsh, W. L.: The recessive $\mathrm{Lu}(\mathrm{a}-\mathrm{b}-)$ phenotype. Vox Sang. 26 . 259-264 (1974).

3 Cleghorn, T. E.: The inheritance of the antigen Swa, and evidence for its independence of other blood group systems. Br. J. Haemat. 6 : 433-438 (1960).

4 Gralníck, M. A.; Goldfinger, D.; Hatfield, P. A.: Reid, M. E., and Marsh, W. L.: Anti-Lu 11. Another antibody defining a high frequency antigen related to the Lutheran blood group system. Vox Sang. 27: 52-56 (1974).

5 Marsh, W. L.: Anti-Lu5, anti-Lu6 and anti-Lu7. Three antibodies defining high frequency antigens related to the Lutheran blood group system. Transfusion 22: 27-34 (1972).

6 Marsh, W. L.: Scoring of hemagglutination reactions. Transfusion 12: 352-353 (1972).

7 Macllroy, M.; McCreary, J., and Stroup, M. J.: Anti-Lu8, an antibody recognizing another Lu- 
theran related antigen. Vox Sang. 23: 455457 (1972).

8 Metaxas-Bühler, M.: Metaxas, M. N., and Giles, C. M.: A Swiss family showing inheritance of the Swann antigen with Lua. Vox Sang. 23: 429-432 (1972).

9 Mohr, J.: A search for linkage between the Lutheran blood group and other hereditary characters. Acta path. microbiol. scand. 28: 207-210 (1951).

10 Molthan, L.; Crawford, M. N.; Marsh, W. L.. and Allen, F. H., jr.: Lu9, another new antigen of the Lutheran blood group system. Vox Sang. 24: 468-471 (1973).
11 Sinclair, M.; Buchanan, D. I.; Tippett, P., and Sanger, R.: Another antibody related to the Lutheran blood group system (Much). Vox Sang. 25: 156-161 (1973).

12 Sanger, R. and Race, R. R.: The Lutheransecretor linkage in man: support for Mohr's findings. Heredity 12: 513-520 (1958).

W. L. Marsh, New York Blood Center, 310 East 67th Street, New York, NY 10021 (USA) 